\title{
BRACKENRIDGIA ASHLEYI (ISOPODA: TRICHONISCIDAE): RANGE EXTENSION WITH NOTES ON ECOLOGY
}

\author{
Michael E. Slay ${ }^{*}$ and Steven J. Taylor ${ }^{2}$
}

\begin{abstract}
We collected Brackenridgia ashleyi from ten caves in Arkansas and Missouri. From the type locality at Tumbling Creek Cave, Taney County, Missouri, we extended the range of the species $138 \mathrm{~km}$ north-northeast into Pulaski County, Missouri, $67 \mathrm{~km}$ south-southwest into Newton County, Arkansas, and $96 \mathrm{~km}$ southeast into Izard County, Arkansas. The new records reported here, in combination with detection of this species at previously inventoried sites, suggest that this species is widely distributed in the Ozarks. However, the relatively intensive sampling efforts required indicate the B. ashleyi is rare and easily overlooked.
\end{abstract}

\section{INTRODUCTION}

The genus Brackenridgia (Isopoda: Trichoniscidae) includes ten species, nearly all described from subterranean habitats, mostly in the western United States and Mexico (Lewis, 2004). With the exception of $B$. heroldi in California, all of the species are troglobionts (Sket, 2008) and occur in widely separated karst areas. Brackenridgia cavernarum has the widest distribution, known from two areas in Texas and one location in New Mexico (Lewis, 2004). Three species are known from individual caves: $B$. sphinxensis (Arizona; Shultz, 1984), B. palmitensis (Mexico; Reddell, 1981, p. 95), and B. ashleyi described on the basis of specimens from Tumbling Creek Cave, Taney County, Missouri, by Lewis (2004).

In Missouri, trichoniscid isopods were reported from Tumbling Creek Cave, Missouri (Craig, 1975; Gardner, 1986), and these specimens ultimately were included in the description of $B$. ashleyi by Lewis (2004). In addition to $B$. ashleyi, other trichoniscids have been recorded from caves in the Ozark ecoregion of Arkansas, Missouri, and Oklahoma. Gardner (1986) reported, from several caves in Carter, Crawford, Howell, and Taney counties in the Missouri Ozarks, Miktoniscus and Amerigoniscus (as Caucasonethes; North American Caucasonethes were placed in Amerigoniscus by Vandel (1950, 1977)). In Arkansas, Miktoniscus has been reported from Clay Cave, Izard County (McDaniel and Smith, 1976), and from Foushee Cave, Independence County (Youngsteadt and Youngsteadt, 1978). Recent records of trichoniscids in Arkansas (Graening et al., 2007) include Brackenridgia from a cave in Marion County, Haplothalmus danicus from a cave in Benton County, and Miktoniscus (determined by G. Schultz) from single caves in Newton and Searcy counties. We report new records from caves in Missouri and Arkansas, broadening the range of B. ashleyi to include much of the central Ozarks and changing its global conservation status, an assessment of extinction risk as defined by NatureServe (2011), through addition of new localities.

\section{Materials And Methods}

During 2003-2009, we collected B. ashleyi from caves in Missouri and Arkansas. Usually, we discovered individuals by visually inspecting woody debris, animal feces, or other organic material. In several caves, we recorded soil temperature $(2 \mathrm{~cm}$ below the surface), air temperature $(10 \mathrm{~cm}$ above the surface), and relative humidity to further define the habitats that yielded trichoniscid isopods. We preserved specimens in 70 to $80 \%$ ethanol and sent them to J. J. Lewis for identification. Specimens from Arkansas were deposited in the University of Arkansas Arthropod Museum, Fayetteville. Specimens from Missouri were deposited in the Crustacean Collection at the Illinois Natural History Survey, Champaign.

\section{RESUlts}

New localities and records for Brackenridgia ashleyiArkansas: Izard County, Clay Cave, 10 July 2008, M. Slay and M. Kottmyer, 1 individual (Dark 2). Marion County, Forest Trail Ridge Cave, 8 June 2004, M. Slay and C. Bitting, 1 individual (087 Hand); 12 June 2008, M. Slay, D. Fong, and M. Kottmyer, 11 individuals; Forest Trail Pit, 11 June 2008, M. Slay, D. Fong, and M. Kottmyer, 2 individuals; Overlook(ed) Cave, 11 June 2008, M. Slay, D. Fong, and M. Kottmyer, 2 individuals. Newton County, Toney Barnes Cave, 16 September 2004, M. Slay and C. Bitting, 1 individual. Stone County, Blanchard Springs Caverns, 11 March 2009, M. Slay and M. Kottmyer, 3 individuals (Dripstone Tour behind first set of bleachers); Rowland Cave, 14 August 2008, M. Slay, C. Slay, and M. Kottmyer, 6 individuals (start of Breakdown passage), 1 ovigerous female (between station

\footnotetext{
* Corresponding Author

${ }^{1}$ The Nature Conservancy, 601 North University Avenue, Little Rock, AR 72205, USA mslay@tnc.org

${ }^{2}$ Illinois Natural History Survey, University of Illinois at Urbana-Champaign, 1816 South Oak Street, Champaign, IL 61820, USA sjtaylor@illinois.edu
} 
D and station E); Upper Shelter Cave, 11 July 2008, M. Slay and M. Kottmyer, 12 individuals. Missouri: Pulaski County, Andy's Cave \#2, 11 April 2004, S. Taylor, M. Slay, and JoAnn Jacoby, 6 individuals (335 Hand); Martin Cave, 23 March 2003, S. Taylor and V. Block, 1 individual (MAR-002 Hand), 29 March 2003, S. Taylor and V. Block, 1 individual (362 Hand), 1 individual (316 Hand).

New localities and records for Brackenridgia sp.Arkansas: Marion County, Morning Star Mine \#6, 26 May 2004, M. Slay and C. Bitting, 1 individual (034 Hand); Toney Bend Mine \#3, 23 July 2004, M. Slay and C. Bitting, 4 individuals (122 Hand), 3 individuals (120 Hand). Missouri: Pulaski County, Wilson Cave, 5 January 2004, S. Taylor and M. Slay, 1 individual (093 Hand), 8 January 2004, S. Taylor and M. Slay, 2 individuals (159 Hand).

In Rowland Cave, we collected B. ashleyi on moist soil mixed with old bones of bats, organic debris, and rocks. In Clay Cave, we collected specimens on clay floors from old, blackened, damp wood full of casings and feces. Similarly, in Blanchard Springs Caverns, we collected individuals from damp pieces of decayed wood; however, the pieces of wood were on top of rocks in a large pile of breakdown blocks. In Pulaski County, Missouri, we always collected the species on clay floors, sometimes with scattered bat guano present. All of our collections and observations of this isopod occurred in sections of caves characterized by complete darkness. In four caves (Clay Cave, Forest Trail Ridge Cave, Martin Cave, and Rowland Cave), we recorded temperature and relative humidity at locations where $B$. ashley $i$ was present. Average temperature of the soil $(\mathrm{n}=14)$ was $13.6{ }^{\circ} \mathrm{C}\left(\mathrm{SE} \pm 0.3{ }^{\circ} \mathrm{C}\right)$ with a range of $12.1-16.6{ }^{\circ} \mathrm{C}$. Average temperature of the air $(\mathrm{n}=13)$ was $14.3{ }^{\circ} \mathrm{C}\left(\mathrm{SE} \pm 0.3{ }^{\circ} \mathrm{C}\right)$ with a range of $13.1-17.1{ }^{\circ} \mathrm{C}$. Average relative humidity $(\mathrm{n}=13)$ was $94.6 \%(\mathrm{SE} \pm 1 \%)$ with a range of $85.5-98.2 \%$.

Collectively, we observed the species during all seasons and in eight (January, March, April, May, June, July, August, and September) of the twelve calendar months. In Martin Cave, we consistently observed the species during four visits over a period of nineteen months (documenting it in March 2003 and January, May, and September 2004). In Blanchard Springs Caverns, we observed it twice over a five-month period (March and July 2009). At a smaller time scale, daily visits to several caves in Arkansas over a period of five days in June 2008 yielded some consecutive observations of $B$. ashleyi. In Forest Trail Pit, we observed individuals the first four days, but not the final day. In Overlook(ed) Cave, we observed individuals the first three days, but not the last two days.

Overall, when any individuals were found, the number was low, with fewer than five individuals observed $87 \%$ of the time. Of 30 observations, 17 detected a single individual, 9 detected two to four individuals, and 4 yielded more than five individuals. We observed the greatest numbers of individuals in Rowland Cave, Forest Trial Ridge Cave, and Upper Shelter Cave, where ten, eleven, and twelve individuals of $B$. ashleyi were observed, respectively.

Bioinventories in Pulaski County, Missouri, included fifty-seven caves, thirty-three of which were visited on more than one occasion for bioinventory using timed-area searches, pitfall trapping, or quadrat sampling. Qualitative sampling was conducted at the remaining caves, but this isopod was only detected in three of the caves in Pulaski County.

\section{Discussion}

Brackenridgia ashleyi is now confirmed from ten additional sites in Arkansas and Missouri, and these new locations extend the range of the species $138 \mathrm{~km}$ north-northeast into Pulaski County, Missouri, $67 \mathrm{~km}$ south-southwest into Newton County, Arkansas, and $96 \mathrm{~km}$ southeast into Izard County, Arkansas, from the type locality at Tumbling Creek Cave, Taney County, Missouri (Fig. 1). Specimens of Brackenridgia were collected from three other caves, but these individuals could not be identified to species. It is possible that these three caves also are locations for $B$. ashleyi, but additional specimens are needed for confirmation. Earlier records attributed to other genera may, in part, be misidentifications of B. ashleyi (such as records of Miktoniscus in Arkansas and Missouri; Lewis, 2004). Several caves where we recorded this species had been sampled previously for macroinvertebrates, notably Blanchard Springs Caverns and Rowland Cave, which were inventoried by Graening et al. (2003). The new records reported here, in combination with detection of this species at previously inventoried sites, suggest that this species is widely distributed in the Ozarks. However, the relatively intensive sampling efforts required indicate the $B$. ashleyi is rare and easily overlooked.

\section{ACKNOWLEDGEMENTS}

We thank J. J. Lewis (Lewis and Associates LLC) for identifying material and persons listed in records of collection for assistance during fieldwork. S. R. Ahler (University of Kentucky), J. Proffitt, K. Lohraff, and R. Edging (Natural Resources Branch, Fort Leonard Wood, Missouri) provided critical advice and information for fieldwork in Missouri. Funding and logistical support was provided by the Arkansas Game and Fish Commission, The Nature Conservancy (Arkansas Field Office), the Illinois State Museum Society, the United States Army Corps of Engineers, the United States Forest Service (Ozark National Forest), and the United States National Park Service (Buffalo National River). 


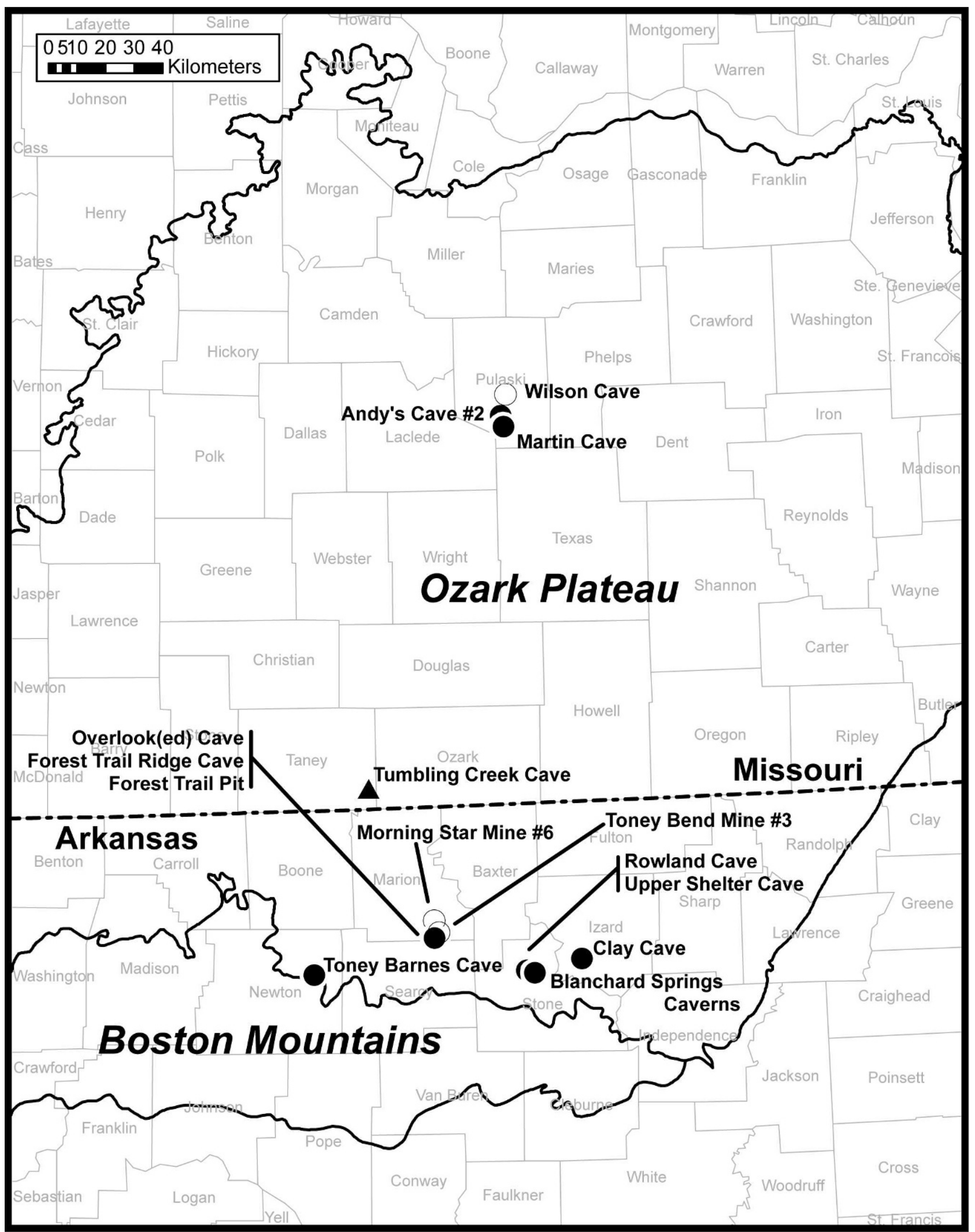

Figure 1. Known distribution of Brackenridgia ashleyi (closed circles, triangle) showing type locality (triangle) and Brackenridgia sp. (open circles, material probably attributable to this species). 


\section{REFERENCES}

Craig, J.L., 1975, A checklist of the invertebrate species recorded from Missouri subterranean habitats: Missouri Speleology, v. 15, no. 2, p. 1-10

Gardner, J.E., 1986, Invertebrate Fauna from Missouri Caves and Springs: Missouri Department of Conservation Natural History Series No. 3, 72 p.

Graening, G.O., Slay, M.E., Fenolio, D.B., and Robinson, H.W., 2007, Annotated checklist of the Isopoda (Subphlyum Crustacea: Class Malacostraca) of Arkansas and Oklahoma, with emphasis on subterranean habitats: Proceedings of the Oklahoma Academy of Science, v. 87, p. 1-14.

Graening, G.O., Slay, M.E., and Tinkle, K., 2003, Subterranean biodiversity of Arkansas, part 1: bioinventory and bioassessment of caves in the Sylamore Ranger District, Ozark National Forest, Arkansas: Journal of the Arkansas Academy of Sciences, v. 57, p. $44-58$.

Lewis, J.J., 2004, Brackenridgia ashleyi, a new species of terrestrial isopod from Tumbling Creek Cave, Missouri (Isopoda: Oniscidea: Trichoniscidae) Proceedings of the Biological Society of Washington, v. 117, p. 176-185.

McDaniel, V., and Smith, K., 1976, Cave fauna of Arkansas: selected invertebrate taxa: Proceedings of the Arkansas Academy of Science, v. 30 , p. $57-60$.
NatureServe, 2011, NatureServe Explorer: An online encyclopedia of life [web application], Version 7.1, NatureServe, Arlington, Virginia, http://www.natureserve.org/explorer, [accessed 18 May 2011].

Reddell, J.R., 1981, A Review of the Cavernicole Fauna of Mexico, Guatemala, and Belize, Austin, Texas Memorial Museum bulletin 27, $327 \mathrm{p}$.

Schultz, G.A., 1984, Brackenridgia sphinxensis n. sp. from a cave with notes on other species from Arizona and California (Isopoda, Oniscoidea): The Southwestern Naturalist, v. 29, p. 309-319.

Sket, B., 2008, Can we agree on an ecological classification of subterranean animals?: Journal of Natural History, v. 42, p. 1549 1563. doi: $10.1080 / 00222930801995762$.

Vandel, A., 1950, Biospeologica LXXI. Campagne spéologique de C. Bolivar et R. Jeannel dans l'Amerique du Nord (1928). Isopodes terrestres recueillis par C. Bolivar et R. Jeannel (1928) et le Dr. Henrot (1946): Archives de Zoologie expérimentale et générale, v. 87, p. $183-210$.

Vandel, A., 1977, Les espèces appartenant au genre Amerigoniscus Vandel, 1950 (Crustacés, Isopodes, Oniscoïdes): Bulletin de la Société d'Histoire naturelle de Toulouse, v. 113, p. 303-310.

Youngsteadt, N., and Youngsteadt, J., 1978, Biosurvey of invertebrates in Foushee Cave, IN-371, with notes on vertebrate observations: AACtivitieS, v. 84 , p. $12-15$. 